\title{
Evaluation of Performance and Degradation Profiles of a Metal Supported Solid Oxide Fuel cell Under Electrolysis Operation
}

\author{
Aziz Nechache ${ }^{\mathrm{a}}$, Feng Han ${ }^{\mathrm{a}}$, Robert Semerad ${ }^{\mathrm{b}}$, Günter Schiller ${ }^{\mathrm{a}}$, Rémi Costa ${ }^{\mathrm{a}}$ \\ ${ }^{a}$ German Aerospace Center (DLR), Institute of Engineering Thermodynamics \\ Pfaffenwaldring 38-40, D-70569 Stuttgart, Germany \\ ${ }^{\mathrm{b}}$ Ceraco Ceramic Coating GmbH, Rote-Kreuz-Str. 8, D-85737 Ismaning, Germany
}

In the context of energy transition, the use of renewable energies through the conversion of different resources with promising technologies into storable energy carriers is of eminent importance for a sustainable energy supply. Hydrogen production from steam using solid oxide electrolysis cells (SOEC) is part of this so called "energy mix". Recently, promising progress appeared from the investigation of metal supports in the solid oxide cell architecture. Metal-supported solid oxide fuel cells (MS-SOFCs) show not only good mechanical strength, relatively low operating temperature $\left(500-750^{\circ} \mathrm{C}\right)$ and improved sealing capability but also low materials cost and tolerance towards rapid thermal cycling and redox cycling (1-3). In the present study, a MS-SOFC was tested under electrolysis conditions. The cell consisted of Ni-catalystloaded $\mathrm{La}_{0.1} \mathrm{Sr}_{0.9} \mathrm{TiO}_{3-\alpha} /$ gadolinium-doped ceria (Ni-LST/GDC) as fuel electrode, gadolinium-doped ceria/yttrium-stabilized zirconia (GDC/YSZ) as electrolyte and $\mathrm{La}_{0.6} \mathrm{Sr}_{0.4} \mathrm{Co}_{0.2} \mathrm{Fe}_{0.8} \mathrm{O}_{3-\delta}$ (LSCF) as $\mathrm{O}_{2}$ electrode. The cell was first tested in fuel cell mode under different gas compositions. Subsequently, a first evaluation of the cell performance profile in electrolysis mode was performed. Thus, a series of current-voltage curves as well as impedance diagrams (under OCV and under load) was recorded. Furthermore, degradation under electrolysis operation was also investigated based on the evolution of the cell voltage against time.

\section{Introduction}

The world is facing key energy issues due to growing demands, depleting fossil fuels and global warming as a consequence of massive greenhouse effect. The combination of wind turbine, solar photovoltaic and fuel cell technologies provides a sustainable solution to the production of renewable and clean energy. Due to its clean, storable and transportable characteristics, hydrogen can be integrated into the energy mix as carbon-free energy carrier (4-6). High temperature electrolysis (HTE) is one of the most efficient ways to produce hydrogen from water and electricity. HTE can be performed on a reversibly operated Solid Oxide Fuel Cell (SOFC), i.e. Solid Oxide Electrolysis Cell (SOEC featuring such advantages as: (i) reduced electrical energy consumption by applying thermal energy, (ii) high gas conversion efficiency, and (iii) avoiding the use of expensive catalyst such as platinum $(4,5,7)$. 
Recently, promising progress appeared from the investigation of metal supports in the solid oxide cell architecture. Metal-supported solid oxide fuel cells (MS-SOFCs) show not only good mechanical strength, relatively low operating temperature $\left(500-750^{\circ} \mathrm{C}\right)$ and improved sealing capability but also low materials cost and tolerance towards rapid thermal cycling and redox cycling (1-3). In the MS-SOFC design, Cr-containing ferritic stainless steels is often applied for the metallic interconnect and porous cell supporting substrate. A dense chromia layer may form on the steel surface and slow down the subsequent oxidation rate at high operation temperature $(8,9)$.

In the present study, a MS-SOFC was tested under electrolysis conditions. The cell was first tested in fuel cell mode under different gas compositions. Subsequently, the cell performance profile in electrolysis mode was evaluated. A series of current-voltage curves as well as impedance diagrams (under OCV and under load) was recorded. Furthermore, degradation under electrolysis operation was also investigated based on the evolution of the cell voltage against time.

\section{Experimental Procedure}

The metal-supported cell tested (further designated as MSC) consisted of Ni-catalystloaded $\mathrm{La}_{0.1} \mathrm{Sr}_{0.9} \mathrm{TiO}_{3-\alpha} /$ gadolinium-doped ceria (Ni-LST/GDC) as fuel electrode, yttriumstabilized zirconia/ gadolinium-doped ceria (8YSZ/GDC) as electrolyte and $\mathrm{La}_{0.6} \mathrm{Sr}_{0.4} \mathrm{Co}_{0.2} \mathrm{Fe}_{0.8} \mathrm{O}_{3-\delta}$ (LSCF) as $\mathrm{O}_{2}$ electrode. A commercial anode-supported cell (further designated as ASC) was also tested as a reference. This cell from CeramTec was made of (Ni-8YSZ) as support and fuel electrode, (8YSZ/GDC) as electrolyte and LSCF as $\mathrm{O}_{2}$ electrode. Both cells have an active area of $16 \mathrm{~cm}^{2}$ and were tested at a working temperature of $750^{\circ} \mathrm{C}$. At the $\mathrm{H}_{2}$ electrode, two fuel gas compositions were considered in fuel cell mode: $96 \% \mathrm{H}_{2}+4 \% \mathrm{H}_{2} \mathrm{O}$ and $80 \% \mathrm{H}_{2}+20 \% \mathrm{H}_{2} \mathrm{O}$. At the $\mathrm{O}_{2}$ electrode, two gas compositions were considered as well: $100 \%$ air and $50 \%$ air $+50 \% \mathrm{~N}_{2}$. In electrolysis mode, all the tests were performed with $80 \% \mathrm{H}_{2} \mathrm{O}+20 \% \mathrm{H}_{2}\left(\mathrm{H}_{2}\right.$ electrode $)$ and air $\left(\mathrm{O}_{2}\right.$ electrode). All the tests under fuel cell and electrolysis conditions were conducted with a flow rate of 2 slpm on both sides. The current density-potential (i-U) curves were recorded in galvanostatic mode with a rate of $24 \mathrm{~mA} / \mathrm{s}$. The electrochemical impedance diagrams were recorded a Zahner IM6 potentiostat and a PP240 booster by applying a dc current with a $500 \mathrm{~mA}$ amplitude perturbation in the frequency range from $100 \mathrm{kHz}$ to $0.5 \mathrm{~Hz}$ for the ASC cell and from $100 \mathrm{kHz}$ to $0.1 \mathrm{~Hz}$ for the MSC cell. The impedance diagrams were recorded for current in the range from $0 \mathrm{~A} / \mathrm{cm}^{2}$ to $0.625 \mathrm{~A} / \mathrm{cm}^{2}$.

\section{Results and Discussion}

\section{Fuel Cell Mode Testing}

The cells were first tested under $96 \% \mathrm{H}_{2}+4 \% \mathrm{H}_{2} \mathrm{O}\left(\mathrm{H}_{2}\right.$ electrode $)$ and air $\left(\mathrm{O}_{2}\right.$ electrode). The i-U curves recorded under these conditions are shown in Figure 1. A clear difference in the OCV value is observed, i.e. $\mathrm{OCV}_{\mathrm{ASC}}=1074 \mathrm{mV}$ while $\mathrm{OCV}$ MSC $=953$ $\mathrm{mV}$. This quite significant difference is surely due to a leakage issue with the MSC cell, most probably explained by the not sufficiently dense microstructure of the electrolyte. However, a quite stable $\mathrm{i}-\mathrm{U}$ curve was recorded showing interesting performances: the obtained current at $0.7 \mathrm{~V}$ is $0.64 \mathrm{~A} / \mathrm{cm}^{2}$, meaning a power of $448 \mathrm{~mW} / \mathrm{cm}^{2}$. It is also 
noticeable that contrary to the ASC cell, no activation part is observed in the i-U curve of the MSC cell. In a purely electrochemical point of view, we can consider that the MSC cell works directly at a minimum resistance under fuel cell conditions. Besides, no mass transport limitation was observed for the MSC cell in the recording range of the i-U curve.

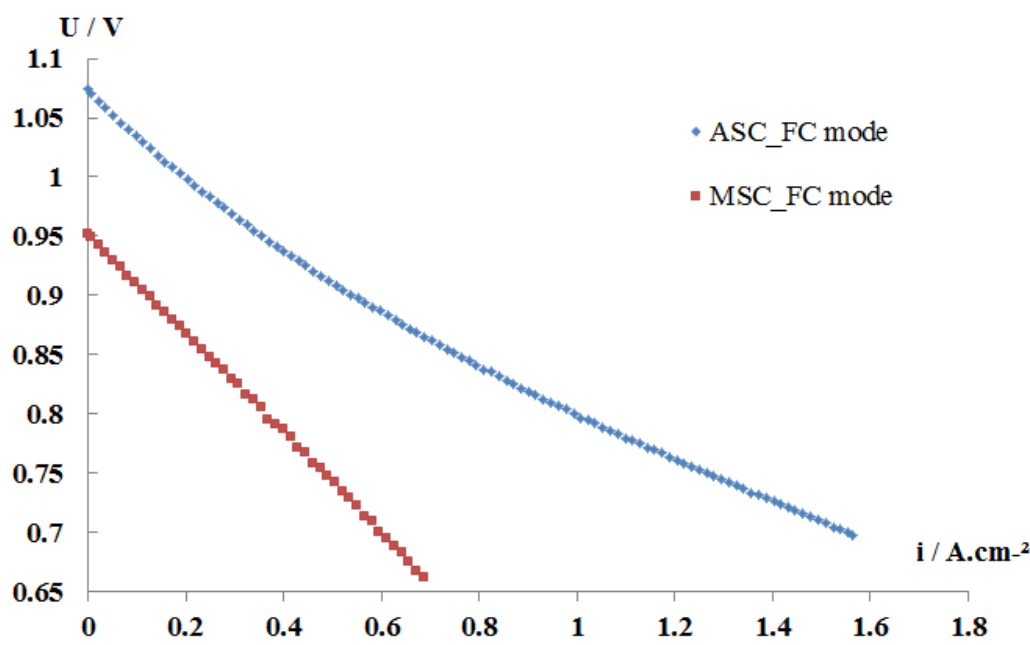

Figure 1. Polarisation curves (i-U curves) of the ASC and MSC cells under fuel cell conditions. $\mathrm{T}=750^{\circ} \mathrm{C}, 96 \% \mathrm{H}_{2}+4 \% \mathrm{H}_{2} \mathrm{O}\left(\mathrm{H}_{2}\right.$ electrode $)$, air $\left(\mathrm{O}_{2}\right.$ electrode $)$, flow rate of 2.0 slpm on both sides.
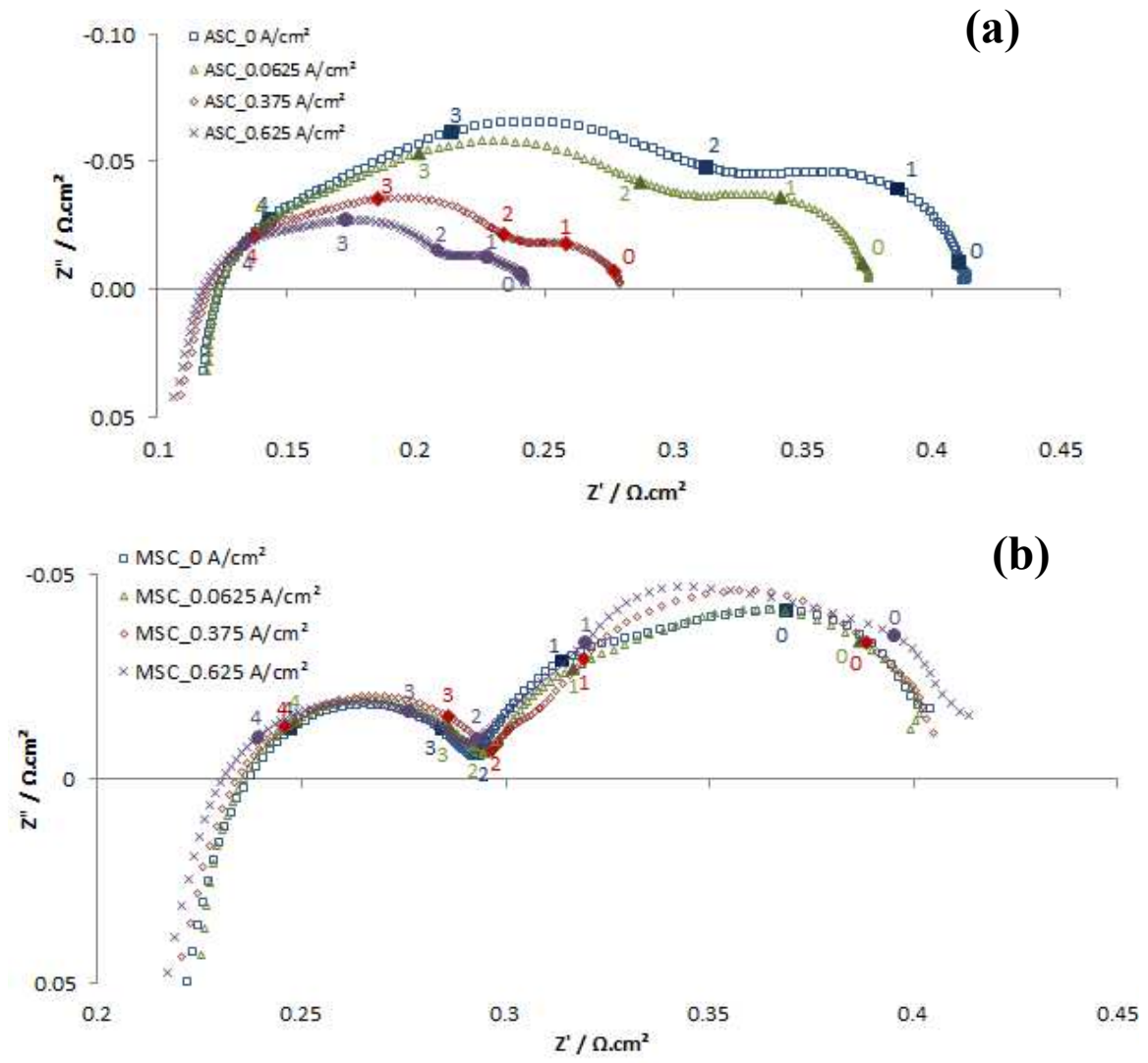

Figure 2. Impedance diagrams of the (a) ASC and (b) MSC cells under fuel cell conditions for different currents between $0 \mathrm{~A} / \mathrm{cm}^{2}, 0.0625 \mathrm{~A} / \mathrm{cm}^{2}, 0.375 \mathrm{~A} / \mathrm{cm}^{2}$ and 0.625 $\mathrm{A} / \mathrm{cm}^{2} . \mathrm{T}=750^{\circ} \mathrm{C}, 96 \% \mathrm{H}_{2}+4 \% \mathrm{H}_{2} \mathrm{O}\left(\mathrm{H}_{2}\right.$ electrode $)$, air $\left(\mathrm{O}_{2}\right.$ electrode $)$, flow rate of 2.0 slpm on both sides. 
Impedance diagrams were recorded under several currents from 0 to $0.625 \mathrm{~A} / \mathrm{cm}^{2}$, as shown in Figure 2. The ohmic resistance $\left(\mathrm{R}_{\Omega}\right)$ for the ASC cell is more than half lower than the MSC cell for all the currents, with values of $115-123 \mathrm{~m} \Omega . \mathrm{cm}^{2}$ and 232-238 $\mathrm{m} \Omega . \mathrm{cm}^{2}$, respectively. The higher ohmic resistance observed in the case of MSC cell might be related to higher interfacial resistances. Besides, $\mathrm{R}_{\Omega}$ barely changes with the current for both cells. The behavior of the polarization resistance $\left(R_{p}\right)$ with the current clearly differs, reflecting the differences in cell behavior observed in the i-U curves. Indeed, while $\mathrm{R}_{\mathrm{p}}$ drastically decreases from 294 to $128 \mathrm{~m} \Omega . \mathrm{cm}^{2}$ for the ASC cell, only a very slight increase from 165 to $176 \mathrm{~m} \Omega . \mathrm{cm}^{2}$ is observed for the MSC cell. All the main electrochemical processes are being activated with the current increase in the case of the ASC cell.

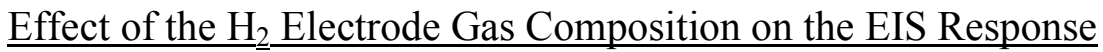

Figure 3 shows the impedance diagrams recorded under $80 \% \mathrm{H}_{2}+20 \% \mathrm{H}_{2} \mathrm{O}\left(\mathrm{H}_{2}\right.$ electrode) and air $\left(\mathrm{O}_{2}\right.$ electrode) for several currents from 0 to $0.625 \mathrm{~A} / \mathrm{cm}^{2}$. Contrary to what was observed in Figure 2, decreasing the $\mathrm{H}_{2}$ content of the gas supplied at the $\mathrm{H}_{2}$ electrode led to an increase of $\mathrm{R}_{\mathrm{p}}$ with current for the MSC cell, from 136 to 161 $\mathrm{m} \Omega . \mathrm{cm}^{2}$, characterized mainly by an increase of the impedance at the lower frequencies $\left(10-10^{-1} \mathrm{~Hz}\right)$ where the electrochemical answer of gas transport processes usually occurs (10) and overlap with anodic processes over LST-CGO based anodes (11). As expected, no significant influence on $\mathrm{R}_{\Omega}$ is noticed.
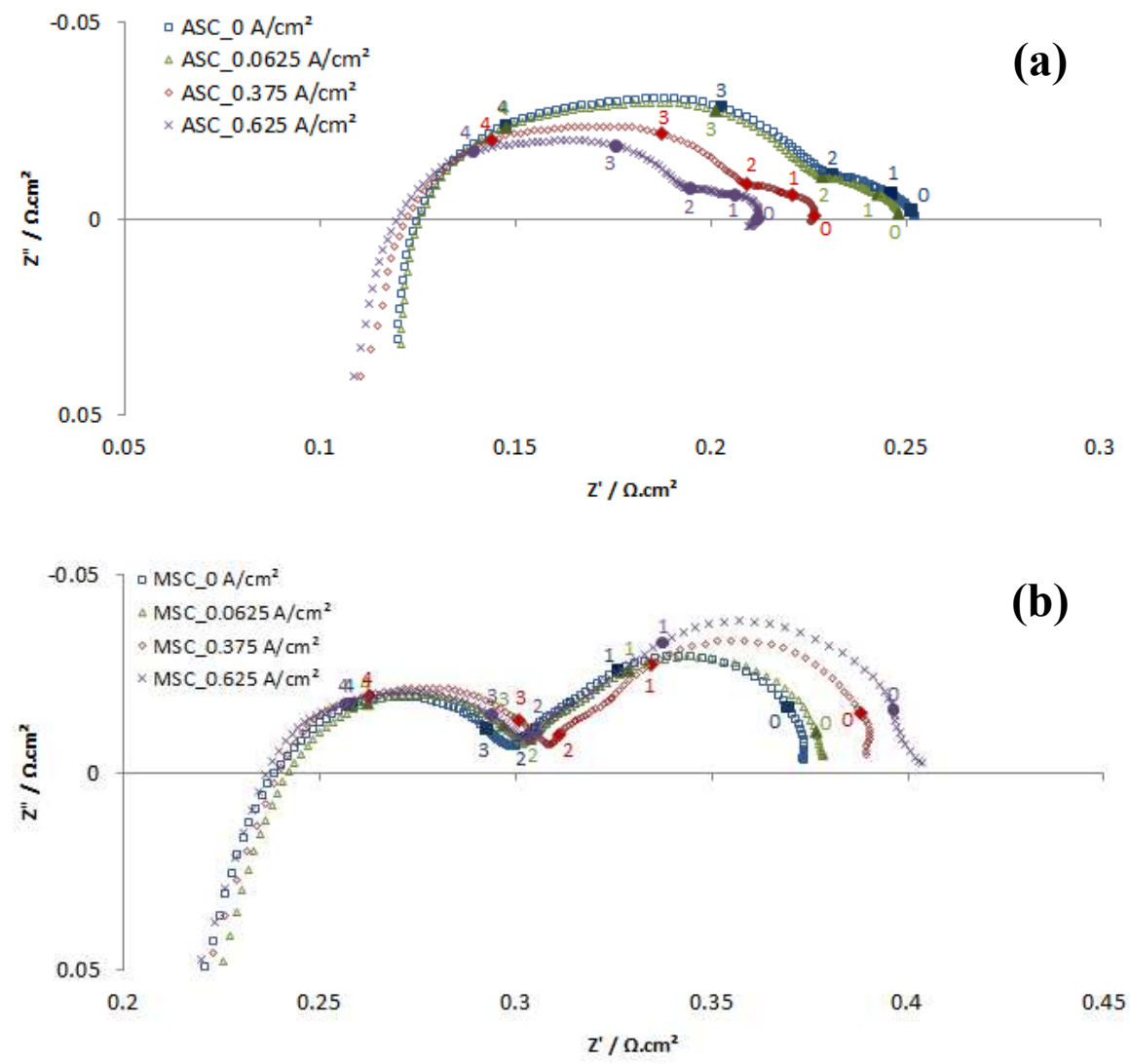

Figure 3. Impedance diagrams of the (a) ASC and (b) MSC cells under fuel cell conditions for different currents between $0 \mathrm{~A} / \mathrm{cm}^{2}, 0.0625 \mathrm{~A} / \mathrm{cm}^{2}, 0.375 \mathrm{~A} / \mathrm{cm}^{2}$ and 0.625 $\mathrm{A} / \mathrm{cm}^{2} . \mathrm{T}=750^{\circ} \mathrm{C}, 80 \% \mathrm{H}_{2}+20 \% \mathrm{H}_{2} \mathrm{O}\left(\mathrm{H}_{2}\right.$ electrode $)$, air $\left(\mathrm{O}_{2}\right.$ electrode $)$, flow rate of 2.0 slpm on both sides. 


\section{Effect of the $\mathrm{O}_{2}$ Electrode Gas Composition on the EIS Response}

Figure 4 shows the impedance diagrams recorded under $96 \% \mathrm{H}_{2}+4 \% \mathrm{H}_{2} \mathrm{O}\left(\mathrm{H}_{2}\right.$ electrode) and $50 \%$ air $+50 \% \mathrm{~N}_{2}\left(\mathrm{O}_{2}\right.$ electrode) for several currents. While a slight $\mathrm{R}_{\mathrm{p}}$ increase is observed for the ASC cell, it is obvious that decreasing the $\mathrm{O}_{2}$ content of the gas supplied at the $\mathrm{O}_{2}$ electrode drastically decreased the MSC cell performances characterized by very important increase of $R_{p}$ with current. Indeed, $R_{p}$ values under $50 \%$ air $+50 \% \mathrm{~N}_{2}$ are over $350 \mathrm{~m} \Omega . \mathrm{cm}^{2}$ while the values did not exceed $180 \mathrm{~m} \Omega . \mathrm{cm}^{2}$ under pure air. Here as well, this increase is mainly characterized by an increase of the impedance at the lower frequencies. Thus, both electrodes are affected by the changes in the gas compositions, as expected in fuel cell mode $(10,12)$.
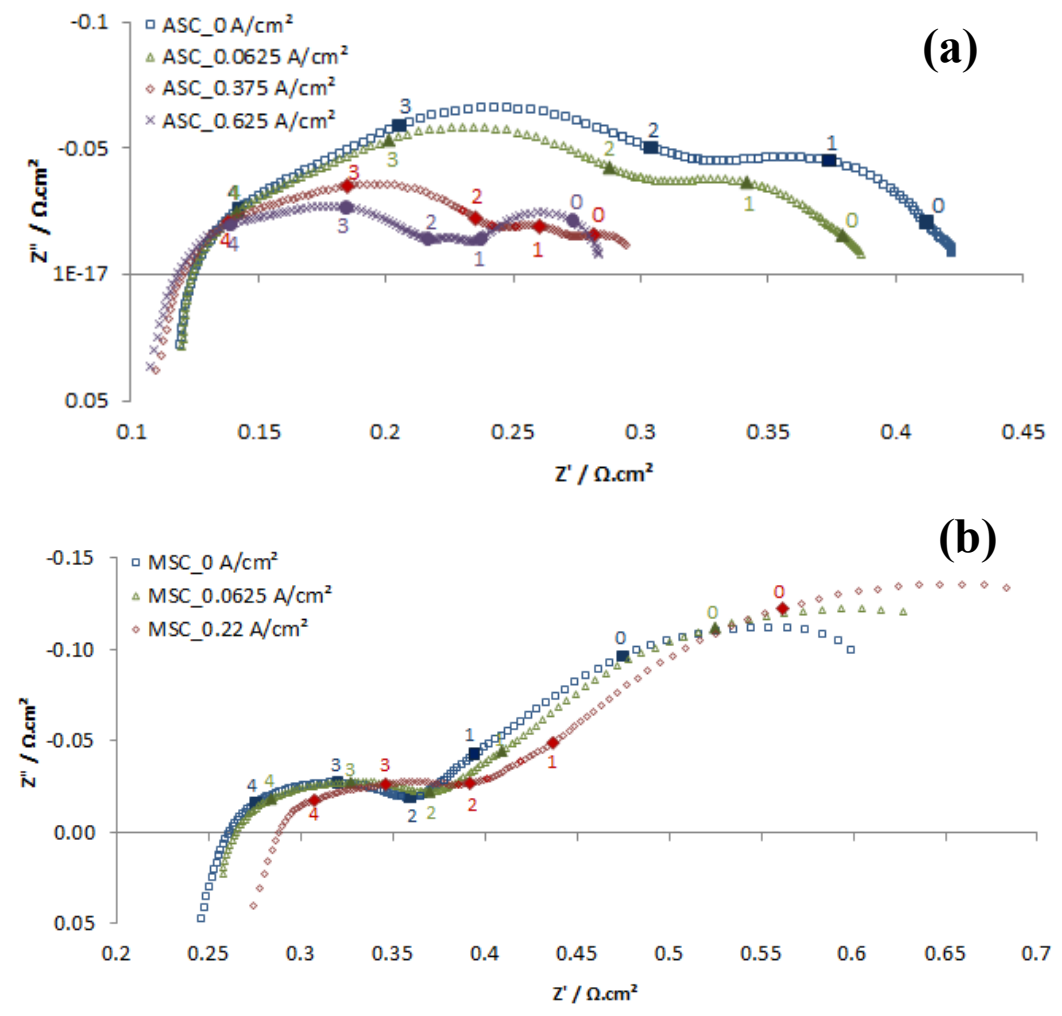

Figure 4. Impedance diagrams of the (a) ASC and (b) MSC cells under fuel cell conditions for different currents between $0 \mathrm{~A} / \mathrm{cm}^{2}$ and $0.625 \mathrm{~A} / \mathrm{cm}^{2} . \mathrm{T}=750{ }^{\circ} \mathrm{C}, 96 \% \mathrm{H}_{2}$ $+4 \% \mathrm{H}_{2} \mathrm{O}\left(\mathrm{H}_{2}\right.$ electrode $), 50 \%$ air $+50 \% \mathrm{~N}_{2}\left(\mathrm{O}_{2}\right.$ electrode $)$, flow rate of 2.0 slpm on both sides.

\section{Electrolysis Mode Testing}

This part shows the first tests of the MSC cell performed in electrolysis mode. The cells were tested under $80 \% \mathrm{H}_{2} \mathrm{O}+20 \% \mathrm{H}_{2}\left(\mathrm{H}_{2}\right.$ electrode $)$ and air $\left(\mathrm{O}_{2}\right.$ electrode $)$. The $\mathrm{i}-\mathrm{U}$ curves recorded under these conditions are shown in Figure 5. A clear difference in the OCV value is observed as in fuel cell mode $\left(\mathrm{OCV}_{\mathrm{ASC}}=890 \mathrm{mV}\right.$ while $\mathrm{OCV}$ MSC $=840$ $\mathrm{mV})$. This difference can here as well be explained by a leakage issue with the MSC cell. However, a quite stable i-U curve was recorded during electrolysis operation showing encouraging performances: the obtained current at the highest voltage of $1.15 \mathrm{~V}$ is 0.75 $\mathrm{A} / \mathrm{cm}^{2}$, meaning a needed power of $863 \mathrm{~mW} / \mathrm{cm}^{2}$, while $815 \mathrm{~mW} / \mathrm{cm}^{2}$ is needed for the ASC cell at this current. It is also noticeable that contrary to the work under fuel cell 
conditions, the $\mathrm{i}-\mathrm{U}$ curve of the MSC cell recorded in this case shows an activation part at lower currents and a mass transport limitation part at higher currents.

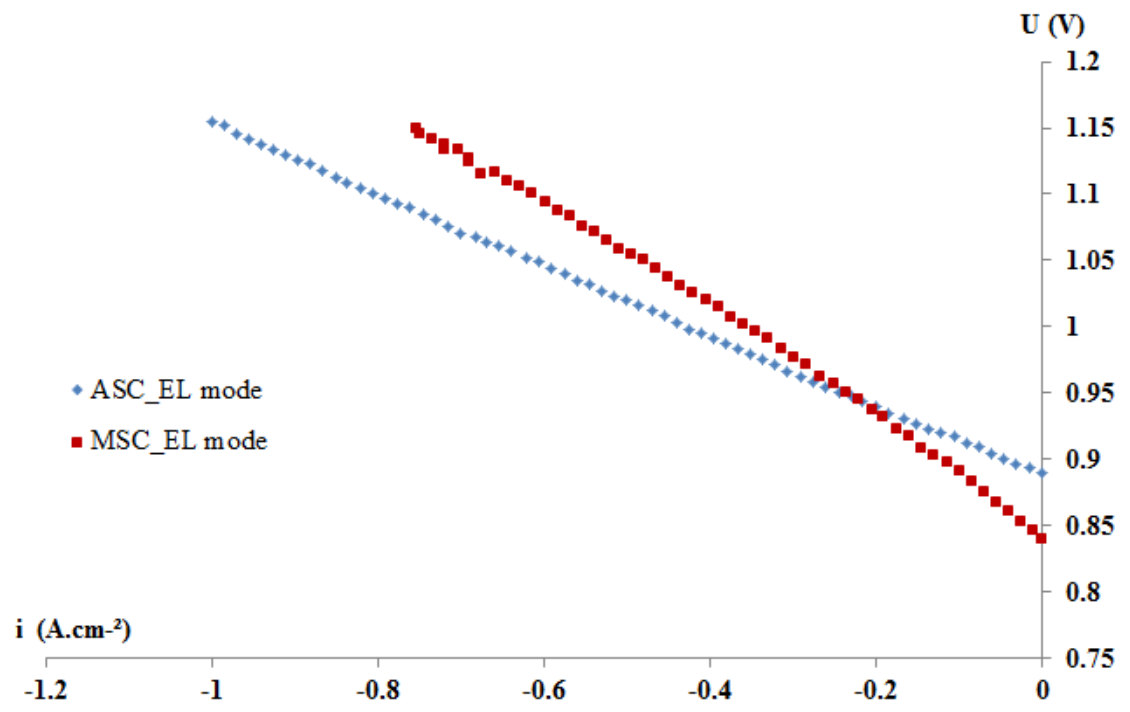

Figure 5. Polarisation curves of the ASC and MSC cells under electrolysis conditions. T $=750^{\circ} \mathrm{C}, 80 \% \mathrm{H}_{2} \mathrm{O}+20 \% \mathrm{H}_{2}\left(\mathrm{H}_{2}\right.$ electrode $)$, air $\left(\mathrm{O}_{2}\right.$ electrode $)$, flow rate of 2.0 slpm on both sides.

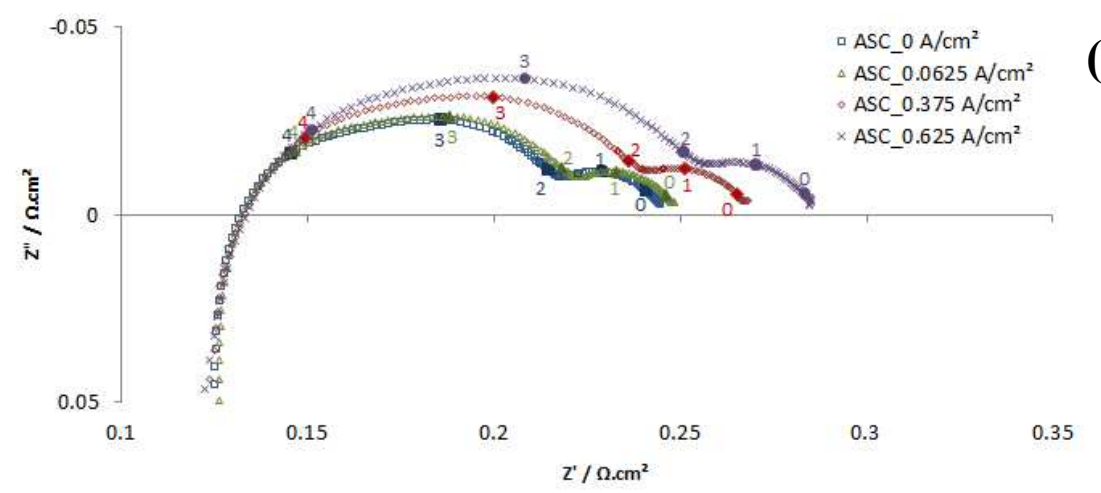

(a)

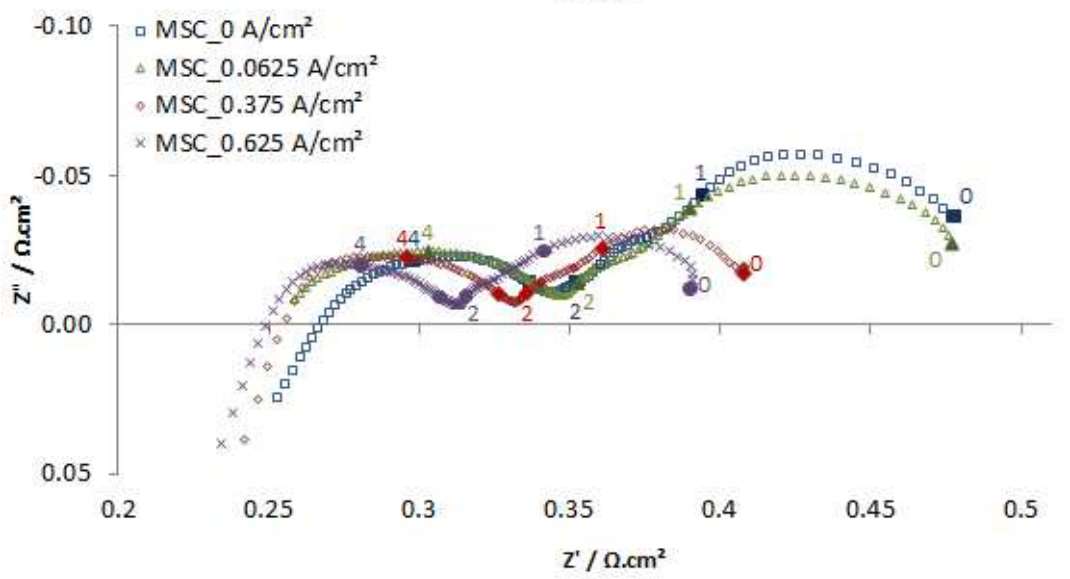

(b)

Figure 6. Impedance diagrams of the (a) ASC and (b) MSC cells under electrolysis conditions for $0 \mathrm{~A} / \mathrm{cm}^{2},-0.0625 \mathrm{~A} / \mathrm{cm}^{2},-0.375 \mathrm{~A} / \mathrm{cm}^{2}$ and $-0.625 \mathrm{~A} / \mathrm{cm}^{2} . \mathrm{T}=750{ }^{\circ} \mathrm{C}, 80 \%$ $\mathrm{H}_{2} \mathrm{O}+20 \% \mathrm{H}_{2}\left(\mathrm{H}_{2}\right.$ electrode $)$, air $\left(\mathrm{O}_{2}\right.$ electrode $)$, flow rate of 2.0 slpm on both sides.

Impedance diagrams were recorded under several currents from 0 to $0.625 \mathrm{~A} / \mathrm{cm}^{2}$, as shown in Figure 6. A more important variation of $\mathrm{R}_{\Omega}$ with the current is observed for the 
MSC cell with values of $249-267 \mathrm{~m} \Omega . \mathrm{cm}^{2}$, while $\mathrm{R}_{\Omega}$ remains constant at $132 \mathrm{~m} \Omega . \mathrm{cm}^{2}$ for the ASC cell. Moreover, the behavior of $\mathrm{R}_{\mathrm{p}}$ with the current reflects here as well the specific MSC cell behavior under electrolysis conditions observed in the $\mathrm{i}-\mathrm{U}$ curves. Indeed, $\mathrm{R}_{\mathrm{p}}$ decreases with the current increase (except for OCV) from $\sim 225$ to $\sim 145$ $\mathrm{m} \Omega . \mathrm{cm}^{2}$. This is characterized by a decrease of the all impedance, meaning that all the main electrochemical processes are activated with current for the MSC cell in electrolysis mode. In the meantime, $\mathrm{R}_{\mathrm{p}}$ clearly increases with current for the ASC cell. In this case, it is mainly the high frequency impedance which seems to be involved, suggesting that, contrary to fuel cell work, the ASC cell needs to be activated in electrolysis mode before optimum performances can be achieved.

\section{Degradation Behavior under Electrolysis Operation}

A first degradation evaluation of the MSC cell under electrolysis conditions was performed by applying $-0.25 \mathrm{~A} / \mathrm{cm}^{2}$ for 120 hours to both cells. Figure 7 shows the i-U curves recorded under $80 \% \mathrm{H}_{2} \mathrm{O}+20 \% \mathrm{H}_{2}\left(\mathrm{H}_{2}\right.$ electrode $)$ and air $\left(\mathrm{O}_{2}\right.$ electrode $)$ initially $\left(\mathrm{t}_{0}\right)$ and after 120 hours $\left(\mathrm{t}_{120}\right)$. Figure 8 shows the evolution of the voltage with time. No OCV change is observed with time, which means that no additional leakage issue is observed for the MSC cell. The i-U curves remains stable with time, with similar shapes for both cells. Besides, a clear performance decrease can be observed for both cells: at $0.75 \mathrm{~A} / \mathrm{cm}^{2}$, the voltage increases from 1149 to $1176 \mathrm{mV}$ for the MSC cell, and from 1086 to $1111 \mathrm{mV}$ for the ASC cell, i.e. $2.3 \%$ for both cells.

However, the voltage evolution with time reveals another aspect in the degradation behavior of the cells. Indeed, while the MSC cell shows a degradation behavior from $\mathrm{t}_{0}$ to $\mathrm{t}_{120}$, the ASC cell shows a strong degradation profile during the first 12 hours to further reactivate, this reactivation being characterized by a decrease of the voltage with time that does not end at $\mathrm{t}_{120}$. Consequently, the MSC cell voltage solely increases from 951 to $964 \mathrm{mV}$ which represents a degradation rate of $13.7 \% / 1000 \mathrm{~h}$, so three times more than the ASC cell overall degradation rate of $4.2 \% / 1000 \mathrm{~h}$.

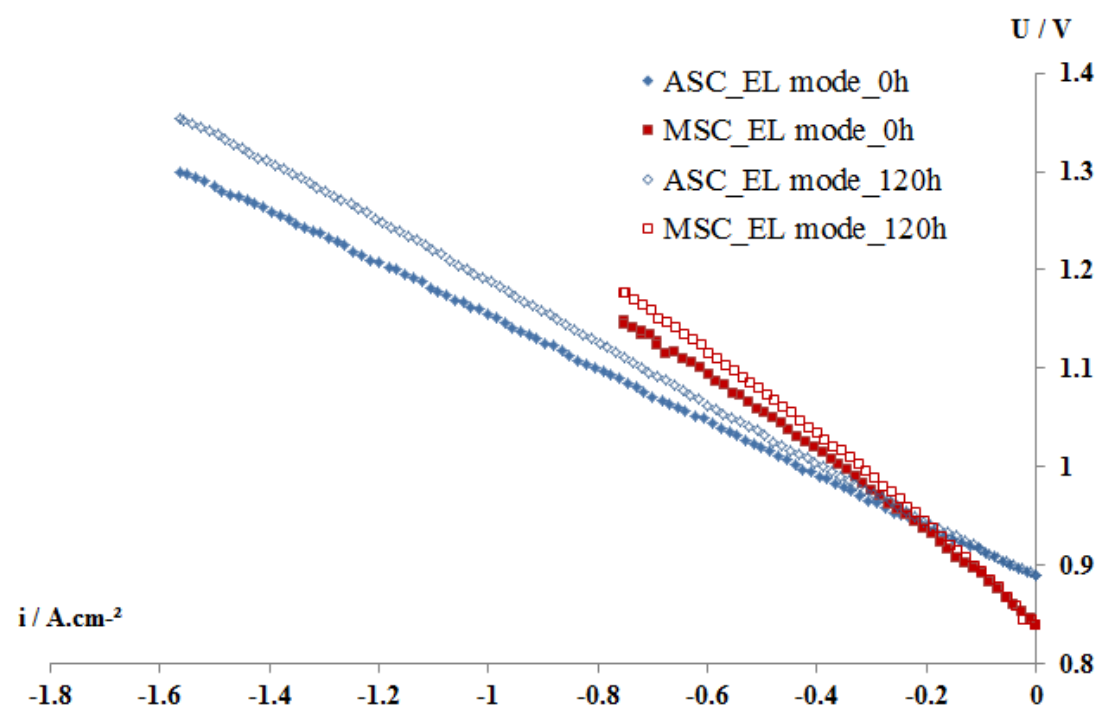

Figure 7. Polarisation curves of the ASC and MSC cells under electrolysis conditions initialy $\left(\mathrm{t}_{0}\right)$ and after 120 hours $\left(\mathrm{t}_{120}\right) . \mathrm{T}=750^{\circ} \mathrm{C}, 80 \% \mathrm{H}_{2} \mathrm{O}+20 \% \mathrm{H}_{2}\left(\mathrm{H}_{2}\right.$ electrode), air $\left(\mathrm{O}_{2}\right.$ electrode $)$, flow rate of $2.0 \mathrm{slpm}$ on both sides. 


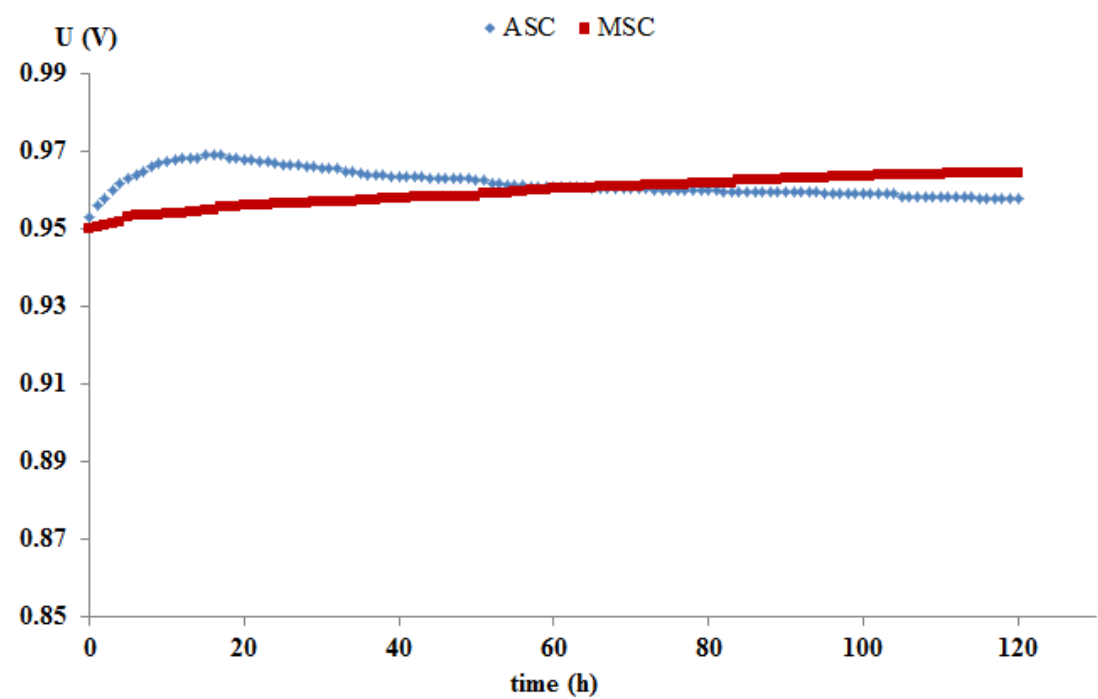

Figure 8. Voltage evolution with time for the ASC and the MSC cells. T $=750^{\circ} \mathrm{C}, \mathrm{i}=-$ $0.25 \mathrm{~A} / \mathrm{cm}^{2}, 80 \% \mathrm{H}_{2} \mathrm{O}+20 \% \mathrm{H}_{2}\left(\mathrm{H}_{2}\right.$ electrode $)$, air $\left(\mathrm{O}_{2}\right.$ electrode $)$, flow rate of 2.0 slpm on both sides.

Figure 9 shows the impedance diagrams recorded for several currents after 120 hours under $-0.25 \mathrm{~A} / \mathrm{cm}^{2}$. A slight $\mathrm{R}_{\Omega}$ increase is observed for both cells with time with values of 270-290 $\mathrm{m} \Omega . \mathrm{cm}^{2}$ for the MSC cell, and $139 \mathrm{~m} \Omega . \mathrm{cm}^{2}$ for the ASC cell. Moreover, it is

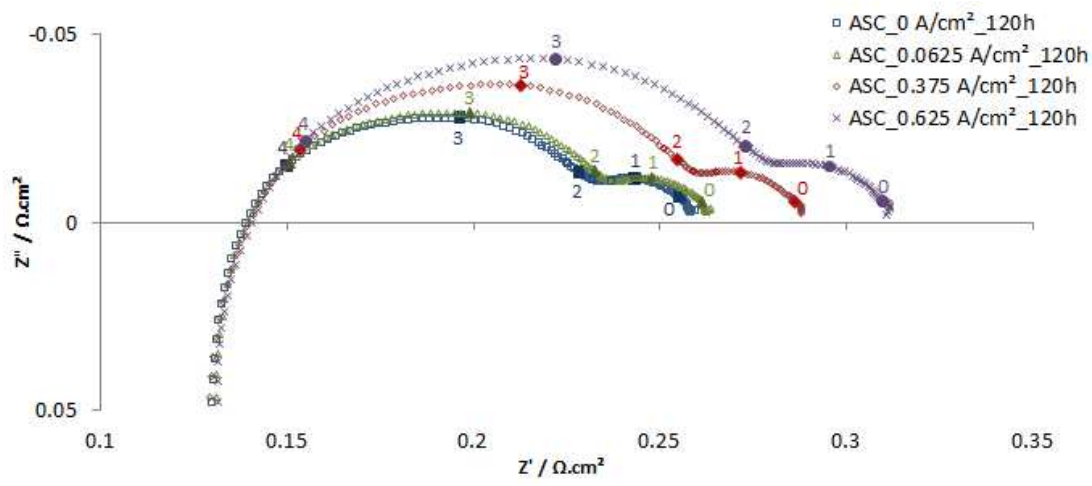

(a)

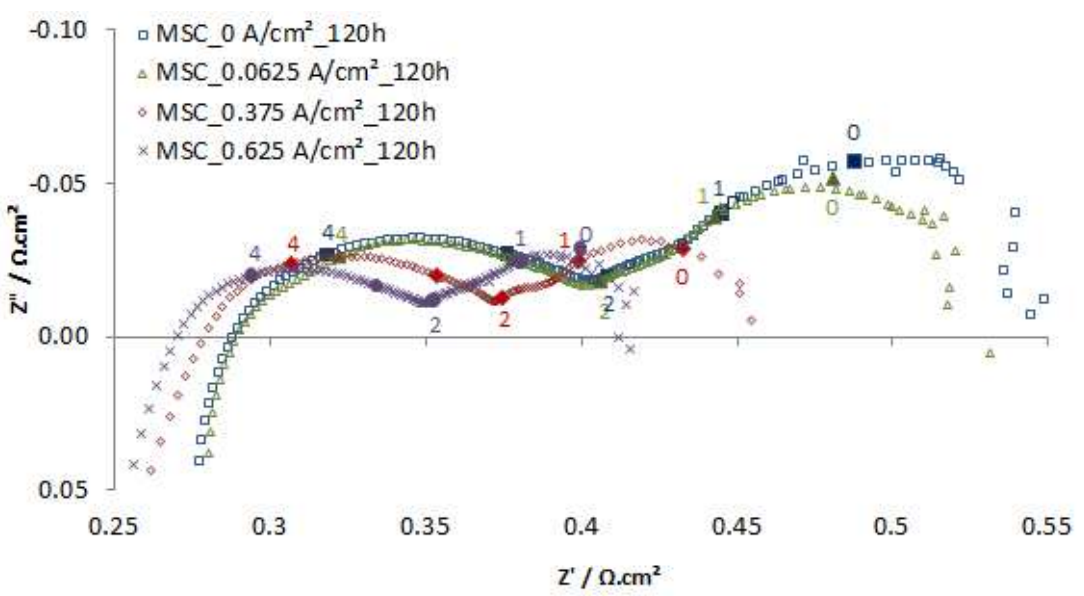

(b)

Figure 9. Impedance diagrams of the (a) ASC and (b) MSC cells after 120 hours under electrolysis conditions for $0 \mathrm{~A} / \mathrm{cm}^{2},-0.0625 \mathrm{~A} / \mathrm{cm}^{2},-0.375 \mathrm{~A} / \mathrm{cm}^{2}$ and $-0.625 \mathrm{~A} / \mathrm{cm}^{2} . \mathrm{T}=$ $750^{\circ} \mathrm{C}, 80 \% \mathrm{H}_{2} \mathrm{O}+20 \% \mathrm{H}_{2}\left(\mathrm{H}_{2}\right.$ electrode $)$, air $\left(\mathrm{O}_{2}\right.$ electrode $)$, flow rate of 2.0 slpm on both sides. 
worth noting for the MSC cell that $\mathrm{R}_{\Omega}$ tends to decrease with increasing currents at both $\mathrm{t}_{0}$ and $\mathrm{t}_{120}$. This is specific to the work under electrolysis conditions and might be explained by a decrease of the interfacial resistances at higher currents. Besides, $\mathrm{R}_{\mathrm{p}}$

behavior remains the same with time for the MSC cell by decreasing with increasing currents from $\sim 255 \mathrm{~m} \Omega . \mathrm{cm}^{2}$ at $0 \mathrm{~A} / \mathrm{cm}^{2}$ to $\sim 145 \mathrm{~m} \Omega . \mathrm{cm}^{2}$ at $-0.625 \mathrm{~A} / \mathrm{cm}^{2}$. Thus, since $\mathrm{R}_{\mathrm{p}}$ barely changed with time, the degradation behavior of the MSC cell can be mainly attributed to the ohmic resistance, meaning a degradation of the electrolyte and/or the contacting at the cell/current collector interface. Meanwhile, the ASC cell is still under activation after 120 hours, as shown by the $R_{p}$ increase with current mainly characterized by the increase of the high frequency impedance.

\section{Conclusion}

In the present study, a MS-SOFC was tested under fuel cell and electrolysis conditions. The cell was first tested in fuel cell mode under different gas compositions. As expected, both electrodes were affected by the changes in the gas compositions which led to an increase of the impedance at the lower frequencies mainly related to gas transport processes. For the optimized gas compositions 96\% $\mathrm{H}_{2} \mathrm{O}+4 \% \mathrm{H}_{2}\left(\mathrm{H}_{2}\right.$ electrode) and air $\left(\mathrm{O}_{2}\right.$ electrode $)$, a power of $448 \mathrm{~mW} / \mathrm{cm}^{2}$ was obtained at $0.7 \mathrm{~V}$. Besides, no activation part and no mass transport limitation were observed in the MSC cell i-U curve. After that, a first electrolysis test was performed on the MSC cell, showing encouraging performances with quite stable $\mathrm{i}-\mathrm{U}$ curve and impedance diagrams recorded. This series of tests ended with a first degradation evaluation of the MSC cell under electrolysis conditions by applying $-0.25 \mathrm{~A} / \mathrm{cm}^{2}$ for 120 hours. The MSC cell showed a degradation rate of $13.7 \% / 1000 \mathrm{~h}$, three times more than the ASC cell overall degradation rate of $4.2 \% / 1000 \mathrm{~h}$.

\section{References}

1. M. C. Tucker, J. Power Sources, 195 (2010) 4570-4582.

2. J. T.S. Irvine, J. Bae, J-Y Park, W. S. Choi, J. H. Kim, Int. J. Hydrogen Energy, 42 (2017) 1212-1220.

3. A. M. Dayaghi, K. J. Kim, S. Kim, J. Park, S. J. Kim, B. H. Park, G. M. Choi, J. Power Sources, 324 (2016) 288-293.

4. M. A. Laguna-Bercero, J. Power Sources, 203 (2012) 4-16.

5. National Academy of Sciences, National Research Council. The hydrogen economy: opportunities, costs, barriers, and R\&D needs, February 2004.

6. M. N. Manage, D. Hodgson, N. Milligan, S. J. R. Simons, D. J. L. Brett, Int. J. Hydrogen Energy, 36 (2011) 5782-5796.

7. W. Dönitz, R. Schmidberger, E. Steinheil, Int. J. Hydrogen Ener., 5 (1980) 55-63.

8. S. Molin, B. Kusz, M. Gazda, P. Jasinski, J. Power Sources, 181 (2008) 31-37.

9. S. Molin, M. Gazda, P. Jasinski, Solid State Ionics, 181 (2010) 1214-1220.

10. A. Leonide, V. Sonn, A. Weber, E. Ivers-Tiffée, J. Electrochem. Soc., 155 (2008) B36-B41.

11. V. Yurkiv, L. Dessemond, F. Han, P. Szabo, R. Semerad, R. Costa, EFCF 2016, B0511, 5-8 July 2016, Lucerne.

12. R. Barfod, M. Mogensen, T. Klemenso, A. Hagen, Y. L. Liu, P. V. Hendriksen, J. Electrochem. Soc., 154 (2007) B371-B378. 